\title{
Marketing Egyptian Crafts Villages for Preserving the Cultural Heritage "Applied on the Nubian Village of Gharb Soheil"
}

Rania Mohamed Bahaa Eldin

Ahmed Adel Hammad

Faculty of Tourism and Hotels, Mansoura University

\begin{abstract}
The crafts' value is widely acknowledged for the cultural heritage, and deserved attention to its different applications in tourism. This illustrates the key role that crafts play in preserving the traditional heritage. This research depended upon primary data through addressing 450 questionnaire forms to tourists: from October 2019 to January, 2020. The number of valid forms was 392 , representing $87.1 \%$. The questionnaires were formed to shed light on the role of crafts villages as a way towards preserving the Egyptian cultural heritage and identify the tourism marketing process of Gharb Soheil. It also depended upon secondary data related to the research's subject. The findings have revealed that despite the significant cultural value of Gharb Soheil crafts village and the importance of its crafts in preserving a part of the Egyptian cultural heritage, there is no effective marketing for it. The research recommends adopting a marketing plan depending basically upon promotional methods represented in increasing publications concerning Gharb Soheil crafts village and setting up an official website concerning Gharb Soheil and its unique crafts. Furthermore, it recommends carrying out market research for targeting and segmenting tourists and determining their needs and wants. The research also recommends doing post visit and post purchase research for measuring tourists' satisfaction with their visit to the village, and tackling any problems found.
\end{abstract}

Keywords: Heritage, Culture, Crafts, Crafts Villages, Marketing, Gharb Soheil.

\section{Introduction}

Tourism is a complex system that features many interdependent tangible and intangible components, which combine to offer the overall tourism experience and result in realising tourists' satisfaction. Tourism derives its uniqueness from its cultural, social, and traditional components. It needs to develop and sustain its features, so that the transfer and preserve of value, knowledge, traditions, and social life can be ensured (Jian and Thakkar, 2019). A long time ago, crafts have been recognised of their social, cultural, and economic significance (Pollanen, 2012). In spite of the dominance of industrial products in the contemporary world, traditional products i.e. crafts still have the popularity, particularly amongst tourists. Cultural tourists seek high quality authentic crafts that represent the visited destination (Jian and Thakkar, 2019). Therefore, one of tourists' travel motivations is to observe the local cultures, traditions, norms and values represented in crafts (Shakiya, 2018). Crafts require much detailed knowledge of skilled work and gained expertise. The interest in crafts as material cultural objects depends upon facilitating interpersonal interactions, carrying personal and emotional meanings, and mediating self-identity and social space. However, with increased globalisation, products have become more commoditised and craftsmen find their products competing with goods from all over the world (Kouhia, 2012). Because of the importance of crafts, particularly in preserving the cultural heritage, marketing crafts villages in Egypt represented in the Nubian Village of Gharb Soheil is considered a way for developing crafts and craftsmanship in Egypt, and consequently preserving the cultural heritage.

The core problem of this research emerges from the poor marketing campaigns of Egyptian crafts villages including the Nubian crafts village of Gharb Soheil, and as a result they are not wellexploited for the sake of cultural tourism and heritage in Egypt. 
The importance of this research derives from the key role that crafts play in cultural tourism as well as in preserving cultural heritage. Therefore, it identifies the features of Gharb Soheil as an Egyptian crafts site of a real cultural value that can play a part in protecting the Egyptian cultural heritage.

Hence, this research aims at shedding light on the importance of crafts and crafts villages to tourists, identifying the Nubian crafts village of Gharb Soheil and its related crafts, and suggesting a marketing plan to promote it.

\section{Limitations of the study are divided into:}

a- Time limitations, which lasted for four months; from October 2019 to January 2020. This period included the time of collecting theoretical data, distributing online questionnaire forms to tourists from October 2019 to December 2019, and finally the trip which was made to Gharb Soheil in January 2020.

b- Place limitations, which represented in the Nubian crafts village of Gharb Soheil including its bazaars, local crafts' exhibitions, and local crafts' workshops.

\section{Literature review}

\section{The Concept of Crafts in Terms of Cultural Heritage}

The word culture represents different aspects of the local life, as it includes customs and traditions, religion, language, arts, and literature. On the other hand, heritage refers to inherited things from the past, which are transferred from a generation to another (Rouhi, 2017). Therefore, cultural heritage is the term that was coined as a combination of culture and heritage, embracing monuments and collections of objects, as well as inherited traditions or living expressions e.g., social practices, oral traditions, arts, local events, rituals, knowledge, and traditional practices including the knowledge and skills of making traditional crafts (Ribasauskiene and Sumyle, 2016). Crafts are those products; which are made by local people's hands utilising simple tools with diverse domestic materials presented and preserved through sustainable practices and methods (Mustafa, 2011; Dodd and Morgan, 2013). Crafts refer to the creative work of people who utilise natural materials and traditional techniques for making items reflecting heritage, culture and tradition of a certain country or local area. They constitute an important component of the local traditional culture (Wang, 2017), as they have a positive role in representing the value, essence, and uniqueness of the destination by presenting a memorable thought about it (Mustafa, 2011). Crafts have the ability in representing a particular culture of a certain community depending upon craftsmanship and the use of local materials. They include for instance, works of pottery, embroideries, jewelleries, textiles, and handmade works of local materials e.g., fibres, woods, stones, glass, ivory, bones, shells that are available in the area (Mustafa, 2011). Tourists buy crafts because they like to feel connected with domestic traditions and local culture in an increasingly commoditised world, which clearly reflects the importance of crafts in the tourism industry (Mahgoub and Alsoud, 2015). Crafts could be classified according to the materials utilised in making them (Khurana, 2011). Due to the significant and unique cultural heritage retained in crafts, they are considered as a mean for preserving and promoting cultural and artistic traditions. According to Schwarz and Yair (2010), Kouhia (2012) and Jennings (2012), crafts have plenty of benefits, represented in the key role they have in preserving traditional skills, understanding cultures, maintaining a sense of folkloric ideology, understanding and reclaiming of cultural values, harnessing and productising cultural heritage, bringing people together around a shared experience over the time and helping people to interact with creative objects. 


\section{The Concept and Importance of Crafts Villages}

Crafts villages are the core of crafts production where households produce traditional crafts; as a testimony to cultural heritage, so that they can be sold in small and medium scopes. It is also the place in which tourists buy crafts, watch them being made and sometimes participate in their making process. Tourists, either international or domestic, buy crafts as souvenirs or a proof of their memorable visit to a certain place (Gustami et al., 2014; Hieu and Rasovska, 2017). Crafts villages are a one-stop craft destination featuring many crafts' trading units, which gives its visitors the chance to watch a unique variety of crafts as well as craft-related programmes and activities (Shrestha, 2011). According to the report of the World Intellectual Property Organisation (2003); Ahmed (2005) and Luong (2006), the common characteristics of crafts villages can be summarised in the following points:

a- Crafts villages obtain their special nature from local crafts that represent cultural, social, traditional and religious facets of the village.

b- Crafts villages emphasises the idea of authenticity and uniqueness, as they offer products made by local inhabitants, where no two identical pieces can be found.

c- Crafts villages' products are made either individually or collectively by family members. However, there might be a simple use of mechanical means or hand tools without negatively affecting the crafts' handmade nature.

d- Skills of craftsmen in these villages are learnt in either the family or the community where they live in and are inherited from generation to generation.

e- Crafts villages as engaged in the tourism industry are not affected by the tourism seasonality. This is because crafts are regularly produced throughout the year as the work of local inhabitants and consequently, they can be marketed all year long for attracting tourists.

However, there are two different types of crafts villages: traditional and non-traditional. Traditional crafts villages are usually exotic destinations where cultural centres and many genuine and authentic activities for tourists to see and do can be found. They emerge mainly to be utilised for reasons such as branding their traditional products i.e., crafts' branding (Hieu and Rasovska, 2017). On the other hand, non-traditional crafts villages refer to new ones established to meet the new market demand of crafts villages (Luong, 2006). Tourists tend to visit crafts villages to get rid of the daily life stress in a peaceful and quiet place, where they can be offered a whole experience in the natural atmosphere of the social and cultural life (Hieu and Rasovska, 2017). Thus, crafts villages with their local crafts are considered an important component of cultural tourism, as people travel to buy and see local crafts and experience other cultures, traditions and unusual ways of living. In crafts villages, crafts have a high degree of hand-made input, which are sold for profit. The production and sales of crafts represent a considerable percentage of gross domestic product (GDP) for many countries (McAuley and Fillis, 2005; Suthersanen, 2015). It is estimated that tourists spend about 40 percent of their travel budget on crafts products, as recent trends demonstrate that tourism earnings depend more upon the craft component, as a crucial way for realising economic, social, and cultural advantages (Mustafa, 2011). This illustrates the vital role that crafts play in crafts villages' income and employment, and as a tool for reducing poverty (Yang et al., 2018). According to Wicks et al., (2004); Suzuki (2006) and Hien (2012), an advanced crafts industry in crafts villages helps in improving the local inhabitants' life either socially or economically by sustainably preserving the village, as indicated: 
a- Crafts villages help economically in providing different job opportunities for their local inhabitants, in addition to their role in reducing the poverty level, which consequently realises a boost to the destination's economy.

b- Crafts villages help socially in bringing about benefits to the local community by maintaining its values and local culture, preserving its customs and traditions, enhancing the feeling of self-identity and self-esteem, enhancing the tourists' experience, and achieving their satisfaction, and improving the whole destination's image.

c- Crafts villages help in bringing about a real competitive advantage when they can achieve creativity, apply new techniques and implement modern marketing tools to their crafts products.

d- Unique local crafts can serve as an attraction factor in the tourism product of the cultural tourism, particularly for tourists who are keen on buying crafts as souvenirs of their trip. On the other hand, local crafts can serve as a marketing tool when they become a reason for tourists to repeat their visit to the village, share a positive word of mouth about it and buy its local souvenirs.

Crafts villages can be found in many countries around the world. For instance, in the densely populated countryside of the Red River Delta in Vietnam, crafts villages are in the process of being expanded and modernised (Dang et al., 2010). These village are specialised in many local crafts e.g., rattan and bamboo weaving, silk making, cotton fabric textiles and knitted garment products. On the other side, the Vietnamese crafts village of Kim Bong is noted for its wooden crafts (Tissari, 2010). The success reason of these villages is due to their classification into clusters, where specialisation and the division of labour enabled them to create a very flexible production system (Fanchette, 2012). The crafts village of Kasongan in the Indonesian city of Yogyakarta is noted for its ceramic crafts, which play a prominent role in Yogyakarta's tourism development. The village is now experiencing a unique creative period, particularly when it has become more oriented towards meeting the needs of tourist industry in Yogyakarta (Gustami et al., 2014). In India, crafts represent 16 percent of India's total trade and 13 percent of Nepal's as more than 2.18 million people work in this industry (Suthersanen, 2015). Egypt also includes many crafts villages and crafts centres that can be found in different places. In Cairo, the central bazaar area includes workshops, artisan activities and small manufacturing enterprises that produce traditional Egyptian crafts (Fahmi, 2012). Khan El-Khalili and Souk El-Fustat are also instances of places in Cairo that sell these crafts e.g., textiles, spices, candles, tableware, rosaries, metal chandeliers and crafts made of wood, silver, gold, diamond, and precious stones (Balayan, 2006; Geith, 2008*; Hussien, 2018*). Moreover, the village of Naqada in the Egyptian governorate of Qena is noted for the craft of firka; hand-woven natural fibres used as shawls, curtains, bed sheets and tablecloths (Saleh, 2006). In Fayoum governorate, Tunis Crafts Village is noted for its pottery crafts. It is also included on the Egyptian tourism map and attracts tourists for its unique pottery products (Radwan, 2016).

\section{Gharb Sohiel as a Crafts Village Model in Egypt:}

When tourists travel to new destinations, they search for authenticity and look for experiencing new cultures (Elcheikh, 2014). Nubia includes different intangible aspects of Nubian heritage e.g, folkloric performances, the Nubian language and culture, special

\footnotetext{
* In Arabic.

* In Arabic.
} 
festivals and events, gastronomy, the Nubian costumes, local arts and Nubian crafts (Orabi, 2019). When tourism bloomed, plenty of Nubian villagers, particularly women used to sell crafts e.g. beaded necklaces and crocheted items to tourists (Elcheikh, 2018). Tangible and intangible aspects of the Nubian culture have been widely promoted in tourism by Egyptian travel agencies and by Nubians themselves. Nowadays, many Nubians want to make use of their culture to develop a new form of tourism, not only to boost their income but also to affirm their cultural identity (Elcheikh, 2015). In Nubian villages, tourists can have the chance of learning about the Nubian culture, explore sites of heritage, practise the villagers' way of life, enjoy nature and hospitality and buy Nubian crafts (Khalil, 2018). One of these villages is the village of Gharb Soheil, which is located on the western bank of the Nile; opposite to Soheil Island, particularly at about 15 Kilometres to the south of Aswan (El Gamil, 2017). Local residents of the village have different sources of income e.g., formal employment, fishing, agriculture and tourism. Their engagement in tourism includes working in room hiring, hotels, feluccas, taxi driving, folkloric dancing, traditional performances and crafts (Elcheikh, 2016). They are famous for their wicker crafts made of river palm leaves (El Gamil, 2017), which were utilised in the past for decorating houses (Elcheikh, 2016). Furthermore, crafts in Gharb Soheil are varied and include: a- Kuta and Tabaga; food set, bLashira; field mat, c- Gergar; women clothes, d- Gelbab and Emma; traditional men clothes, e- Afro trays, $\mathbf{f}$ - tablemats, $\mathbf{g}$ - laundry baskets, $\mathbf{h}$ - colourful bags and hats, $\mathbf{i}$ - henna drawing, $\mathbf{j}$ beaded accessories, in addition to jewellery made of silver, brass, leather, buffalo horns and precious stones (El Gamil, 2017; Elcheikh, 2018). Shops and bazaars in Gharb Soheil display all kinds of domestic crafts as souvenirs, in addition to wooden sculptures and masks that reflect more Sub-Saharan African features (Elcheikh, 2013). Crafts require trained craftsmen to produce authentic objects as a way for building the destination's image, realising the mentioned economic, social, cultural, environmental advantages, and achieving sustainable aims and goals. However, in many cases, artisans are out of reach and this presents a challenge to those seeking to export their crafts (Mahgoub and Alsoud, 2015). This illustrates the significant role of crafts marketing as way for preserving the cultural heritage.

\section{Marketing Crafts Villages}

Marketing is a societal process by which both of individuals and groups can get what they need through creating, offering and exchanging products and services of value with others. It is a societal function and a systemic set of processes to create, communicate and deliver value to customers, for managing customer and societal relationships in ways that bring about advantages to both of local and global stakeholders of these processes (Gamble et al., 2011). When it comes to the marketing process of crafts villages, it has been revealed that the supply of scattered information as well as unsystematic and insufficient data on production and sales of crafts constitute a major challenge for developing quantitative marketing strategies. Furthermore, the failure of the marketing process in crafts villages can result from inefficient market approaches, which lead to locking out crafts villages from global markets (Khan and Amir, 2013). However, plenty of craftsmen are their own marketeers, as they develop selfselling skills through their personal relations and direct contacts. Hence, effective marketing efforts should be targeted at crafts villages, so that these villages can be promoted and consequently their crafts can be widely sold (Ashley, 2006; Dash and Chodimella, 2011). According to the studies of the United Nations Environment Programme and the World Tourism Organisation (2005); Ashley (2006); and Khan and Amir (2013), the marketing plan for promoting crafts villages should include the following basic elements: 
a- Applying a regular market survey to gather market information so that solution can be offered for tackling market problems.

b- Applying strategic measures for improving the marketing of crafts villages.

c- Carrying out a market research for analysing demand and supply, and identifying tourists' needs and wants.

d- Carrying out a market research for determining village resources and crafts materials, as well as its infrastructure, superstructure, services, and facilities.

e- Adopting a marketing strategy where elements of marketing mix can be planned for.

f- The successful marketing strategy of crafts villages depend upon identifying the appropriate products for targeting them to the suitable market, calculating prices, choosing effective channels of distribution, establishing successful ways of promotion, evaluating sales of crafts, and measuring the tourists' satisfaction by doing post purchase research.

g- Achieving a real product development i.e., the action plan, where taken decisions can be successfully executed.

\section{Methodology:}

Regarding the key role of marketing Egyptian crafts villages for preserving the cultural heritage; applied on the Nubian village of Gharb Soheil, this study depended upon utilising a mixed methodology through incorporating primary and secondary data. The secondary sources were discussed above and included theoretical references concerning the subject of study. The primary data were gathered and presented after distributing questionnaire forms addressed to a random sample of 450 tourists: from October 2019 to January 2020. The total number of valid questionnaires was 392; as 285 questionnaires depended upon online distribution, whereas the other 107 questionnaires were from direct tourists' answers to questionnaires in Gharb Soheil. Because of the importance of Gharb Soheil village as a place where its local crafts represent a significant part of its cultural heritage (Orabi, 2019), this village was chosen to be marketed as a way for preserving the Egyptian cultural heritage. The questionnaire forms consisted of three sections. The first section was designed to obtain demographic data of respondents e.g., gender, age, nationality, social status, educational level, and income average in US dollar. The second section included 9 questions for obtaining general data concerning tourists' acquaintance with crafts villages. The third section used to shed light on the key factors for marketing the Crafts Village of Gharb Soheil. It depended basically upon 30 statements reflecting the tourism marketing mix i.e., product, price, place, promotion, and people concerning Gharb Soheil. This section was designed by posing five-point Likert-type scale questions; "strongly agree $=5$, agree $=4$, neutral $=3$, disagree $=2$ and strongly disagree $=1$ ", in order to determine levels of agreement with the investigated statements as well as identify respondents' perception towards marketing Gharb Soheil village for preserving the Egyptian cultural heritage. The range of each level of agreement was calculated as follow:

- $\quad$ Strongly disagree $=$ from 1 to 1.80

$$
5-1 / 5=0.8
$$

- $\quad$ Disagree $=1.81$ to 2.60

- $\quad$ Neutral $=$ from 2.61 to 3.40

- $\quad$ Agree $=$ from 3.41 to 4.20

- $\quad$ Strongly agree $=$ from 4.21 to 5 
A pre-test was carried out to test wording, layout and completion time. After the forms had been adjusted, they were eventually carried out in three months; from October 2019 to January 2020. Results were statistically analysed by using the SPSS programme; version 25 . The analysed data helped in revealing some important facts concerning the subject of study, and were presented in tables.

As indicated in Table (1), the questionnaire's reliability and validity of this study were measured depending upon Cronbach's Alpha coefficient.

Table 1: Reliability Analysis

\begin{tabular}{|c|c|}
\hline Number of Items & Cronbach's Alpha \\
\hline 39 & 0.834 \\
\hline
\end{tabular}

Table (1) demonstrates that the Cronbach's Alpha Coefficient of the questionnaire's dimensions was 0.834 , which is higher than 0.70 (Pallant, 2016). This finding indicated to the reliability and validity of the questionnaire used in the study.

\section{Results and Discussion}

Section One: Demographic Data:

Question No. 1 Gender:

Table 2: Respondents' Gender

\begin{tabular}{|c|c|c|}
\hline Attributes & Frequency & Percent \\
\hline Males & 172 & 43.9 \\
\hline Females & 220 & 56.1 \\
\hline Total & 392 & 100.0 \\
\hline
\end{tabular}

As indicated in table (2), the data state that females are more than males as $56.1 \%$ of all respondents were females compared to $43.9 \%$ males.

Question No. 2 Age:

Table 3: Respondents' Age

\begin{tabular}{|l|c|c|}
\hline \multicolumn{1}{|c|}{ Attributes } & Frequency & Percent \\
\hline Less than 25 years old & 79 & 20.2 \\
\hline From 25 to less than 45 years old & 211 & 53.8 \\
\hline From 45 to 65 years old & 94 & 24.0 \\
\hline Above 65 years old Total & 8 & 2.0 \\
\hline \multicolumn{1}{|c|}{ Told } & 392 & 100.0 \\
\hline
\end{tabular}

As indicated in table (3), the data state that youth tourists whose age is from 25 to less than 45 years old constituted the highest percentage of $53.8 \%$, followed by tourists whose age is from 45 to 65 years old; representing $24 \%$, followed by tourists whose age is less than 25 years old; representing $20.2 \%$, and finally tourists whose age is above 65 years old constituted the lowest percentage of only $2 \%$. It can be inferred that youth tourists constituted the highest percentage because they have the enough leisure time and have the ability and readiness to travel in their holidays.

Question No. 3 Nationality:

Table 4: Respondents' Nationality

\begin{tabular}{|c|c|c|}
\hline Attributes & Frequency & Percent \\
\hline Egyptian & 228 & 58.2 \\
\hline Foreigner & 164 & 41.8 \\
\hline Total & 392 & 100.0 \\
\hline
\end{tabular}

As indicated in table (4), the data state that Egyptians constituted the highest percentage as $58.2 \%$ of tourists were Egyptians in comparison with $41.8 \%$ foreigners. Foreigners' nationality 
was also identified, and included British, Spanish, French, Germans, Argentineans and Chinese. The majority of tourists were Egyptians; this might be due to the political and environmental circumstances, which have affected negatively on the travel and tourism sector. Furthermore, there is insufficient marketing and promotion plans to attract foreign tourists to the village. Question No. 4 Social Status:

Table 5: Respondents' Social Status

\begin{tabular}{|l|c|c|}
\hline \multicolumn{1}{|c|}{ Attributes } & Frequency & Percent \\
\hline Single & 164 & 41.8 \\
\hline Newly married & 24 & 6.1 \\
\hline With Children & 188 & 48.0 \\
\hline Empty Nester & 16 & 4.1 \\
\hline Total & 392 & 100.0 \\
\hline
\end{tabular}

As indicated in table (5), the data state that tourists who have children constituted the highest percentage; representing $48 \%$, followed by single tourists representing $41.8 \%$, followed by the newly married tourists; representing $6.1 \%$ and finally came the empty nesters who constituted the lowest percent; representing 4.1\%.

Question No. 5 Educational Level:

Table 6: Respondents' Educational Level

\begin{tabular}{|l|c|c|}
\hline \multicolumn{1}{|c|}{ Attributes } & Frequency & Percent \\
\hline Average Education & 55 & 14.0 \\
\hline University Education & 171 & 43.6 \\
\hline Postgraduate Education & 166 & 42.3 \\
\hline Total & 392 & 100.0 \\
\hline
\end{tabular}

As shown in table (6), the data stated that tourists who have a university education constituted the highest percent; representing $43.6 \%$, followed by tourists who have a postgraduate education; representing a percentage of $42.3 \%$, and finally came tourists who have an average education; representing $14 \%$. These results refer to tourists' high level of education in relation to awareness towards culture and heritage concerning Gharb Soheil.

Question No. 6 Respondents Income Average in US dollar:

Table 7: Respondents' Educational Level

\begin{tabular}{|l|c|c|}
\hline \multicolumn{1}{|c|}{ Attributes } & Frequency & Percent \\
\hline Less than $\$ 500$ & 187 & 47.7 \\
\hline From $\$ 500$ to $\$ 1000$ & 128 & 32.7 \\
\hline More than $\$ 1000$ & 77 & 19.6 \\
\hline Total & 392 & 100.0 \\
\hline
\end{tabular}

As indicated in table (7), the data stated that tourists' income average, which is less than $\$ 500$ constituted the highest percentage of $47.7 \%$, followed by tourists whose income average is from $\$ 500$ to $\$ 1000$; representing $32.7 \%$, and finally came tourists whose income average is more than $\$ 1000$; representing $19.6 \%$.

\section{Section Two: Tourists' Acquaintance with Crafts Villages:}

Question No. 7 Is buying crafts constitute an essential component of your trip or tourism experience?

Table 8: Importance of Crafts for Tourists

\begin{tabular}{|c|c|c|}
\hline Attributes & Frequency & Percent \\
\hline Yes & 346 & 88.3 \\
\hline No & 46 & 11.7 \\
\hline
\end{tabular}


As indicated in table (8), the majority of answers indicated that buying crafts constitutes an essential component of tourists' "cultural tourists" trip or tourism experience; representing $88.3 \%$, whilst the minority of answers did not agree with that question; representing $11.7 \%$. These results are consistent with the study of Benson (2014).

Question No. 8 Do you save up money for buying crafts as souvenirs in your trip?:

Table 9: Saving Up for Buying Crafts in Tourism Trips

\begin{tabular}{|c|c|c|}
\hline Attributes & Frequency & Percent \\
\hline Yes & 282 & 71.9 \\
\hline No & 110 & 28.1 \\
\hline Total & 392 & 100.0 \\
\hline
\end{tabular}

As indicated in table (9), the majority of answers demonstrates that tourists do save up money for buying crafts as souvenirs in their trips; representing $71.9 \%$, whilst the minority of answers did not agree with that question; representing $28.1 \%$. This illustrates that the majority of tourists are keen on buying crafts as souvenirs and do save up money for buying them. These findings agree with study of Swanson (2004).

Question No. 9 Have you been to crafts villages in Egypt?

Table 10: Tourists' Visits to Crafts Villages in Egypt

\begin{tabular}{|c|c|c|}
\hline Attributes & Frequency & Percent \\
\hline Yes & 305 & 77.8 \\
\hline No & 87 & 22.2 \\
\hline Total & 392 & 100.0 \\
\hline
\end{tabular}

As indicated in table (10), Egyptian crafts villages are a favourable place of visit to tourists, as the percentage of tourists who have been to Egyptian crafts villages was the highest one; representing $77.8 \%$, whilst $22.2 \%$ have not been to Egyptian crafts villages. Egyptian crafts villages that have been visited by tourists included Kerdasa in Giza, Akhmim in Sohag, Tunis crafts village in Fayoum and crafts villages in Aswan including Gharb Soheil. Some of tourists mentioned to tourist souvenirs centres e.g., Khan El-Khalli in Cairo as the place in which they bought crafts and souvenirs from.

Question No. 10 Have you been to the Egyptian Crafts Village of Gharb Soheil?

Table 11: Tourists' Visits to the Egyptian Crafts Village of Gharb Soheil

\begin{tabular}{|c|c|c|}
\hline Attributes & Frequency & Percent \\
\hline Yes & 281 & 71.7 \\
\hline No & 111 & 28.3 \\
\hline Total & 392 & 100.0 \\
\hline
\end{tabular}

As indicated in table (11), Gharb Soheil crafts village is a favourabe place of visit to tourists, as the percentage of tourists who visited it was the highest; representing $71.7 \%$, whilst the percentage of tourists who did not visit it represented $28.3 \%$.

Question No. 11 If you have been to Gharb Soheil, what was your source of information?:

Table 12: Tourists' Source of Information about Gharb Soheil

\begin{tabular}{|l|c|c|}
\hline \multicolumn{1}{|c|}{ Attributes } & Frequency & Percent \\
\hline Family & 16 & 5.7 \\
\hline Friend & 92 & 32.7 \\
\hline Tour Guide & 101 & 35.9 \\
\hline Travel Agencies & 48 & 17.1 \\
\hline Online Search & 8 & 2.8 \\
\hline Other & 16 & 5.7 \\
\hline
\end{tabular}




\begin{tabular}{|c|c|c|}
\hline Total & 281 & 100.0 \\
\hline$* \mathrm{~N}=281$ &
\end{tabular}

As indicated in table (12), the main source of information about Gharb Soheil for tourists was a tour guide suggestion; representing a percentage of $35.9 \%$, followed by a friend suggestion; representing a percentage of $32.7 \%$, followed by travel agencies suggestion; representing $17.1 \%$, followed by family suggestion; representing $5.7 \%$, the online search represented $2.8 \%$, and other sources e.g. self-searching represented $5.7 \%$. It can be inferred form these data that there is a poor marketing for Gharb Soheil, as the majority of its visits depended upon suggestions form tour guides and friends.

Question No. 12 If you have been to Gharb Soheil, which kind of crafts appealed to you so much?

Table 13: Crafts of Gharb Soheil that Highly Attracted Tourists

\begin{tabular}{|l|c|c|}
\hline \multicolumn{1}{|c|}{ Attributes } & Frequency & Percent \\
\hline Textiles & 39 & 35.1 \\
\hline Embroideries & 8 & 7.2 \\
\hline Wicker Products & 40 & 36.0 \\
\hline Accessories & 24 & 21.6 \\
\hline Total & 111 & 100.0 \\
\hline
\end{tabular}

$* \mathrm{~N}=111$

As indicated in table (13), the wicker products constituted the highest percentage; representing $36 \%$, followed by textiles; representing $35.1 \%$, followed by accessories; representing $21.6 \%$ and then came the embroideries, which constituted $7.2 \%$.

Question No. 13 If you have been to Gharb Soheil, was there a difficulty when visiting it?:

Table 14: Difficulty when Visiting Gharb Soheil

\begin{tabular}{|c|c|c|}
\hline Attributes & Frequency & Percent \\
\hline Yes & 155 & 60.1 \\
\hline No & 103 & 39.9 \\
\hline Total & 258 & 100 \\
\hline
\end{tabular}

$\mathrm{N}=258$

As indicated in table (14), the majority of tourists stated that there was a difficulty when visiting Gharb Soheil; representing $60.1 \%$, whilst the other tourists stated that there was no difficulty when visiting Gharb Soheil; representing 39.9\%.

Question No. 14 If there was a difficulty when visiting Gharb Soheil, what was it from?:

Table 15: Difficulty when Visitng Gharb Soheil

\begin{tabular}{|l|c|c|}
\hline \multicolumn{1}{|c|}{ Attributes } & Frequency & Percent \\
\hline Accessibility & 25 & 16.2 \\
\hline Time Limitation & 16 & 10.3 \\
\hline Lack of Tourist Facilities and Services & 9 & 5.8 \\
\hline Lack of Data & 54 & 34.8 \\
\hline Remoteness of the Village & 51 & 32.9 \\
\hline Total & 155 & 100 \\
\hline
\end{tabular}

$\mathrm{N}=155$

As indicated in table (15), lack of data about the village constituted the highest percentage, representing $34.8 \%$, followed by the remoteness of the village; representing $32.9 \%$, followed by accessibility; representing $16.2 \%$, followed by the time limitation factor; representing $10.3 \%$, and finally came the lack of tourist facilities and services; representing 5.8\%. These difficulties stand 
as weak spots in Gharb Soheil and hinder tourists from visiting it. Therefore, these weak spots must be tackled so that frequent tourists' visits to the village can be guaranteed.

\section{Section Three:}

Table 16: Marketing the Egyptian Crafts Village of Gharb Soheil

\begin{tabular}{|c|c|c|c|c|c|c|c|c|c|}
\hline \multicolumn{10}{|c|}{ a- Product } \\
\hline \multirow[t]{2}{*}{ No. } & \multirow{2}{*}{\multicolumn{2}{|c|}{ Attributes }} & \multicolumn{5}{|c|}{ Responds } & \multirow[t]{2}{*}{ Mean } & \multirow{2}{*}{$\begin{array}{l}\text { Standard } \\
\text { Deviation }\end{array}$} \\
\hline & & & 1 & 2 & 3 & 4 & 5 & & \\
\hline \multirow[t]{2}{*}{1} & \multirow{2}{*}{ You are interested in buying crafts } & Freq. & & 7 & 39 & 212 & 134 & \multirow[t]{2}{*}{4.21} & \multirow[t]{2}{*}{.686} \\
\hline & & $\%$ & & 1.8 & 9.9 & 54.1 & 34.2 & & \\
\hline \multirow[t]{2}{*}{2} & \multirow{2}{*}{$\begin{array}{l}\text { You are interested in crafts making } \\
\text { activities }\end{array}$} & Freq. & & 23 & 79 & 196 & 94 & \multirow[t]{2}{*}{3.92} & \multirow[t]{2}{*}{0.819} \\
\hline & & $\%$ & & 5.9 & 20.2 & 50.0 & 24.0 & & \\
\hline \multirow[t]{2}{*}{3} & \multirow{2}{*}{$\begin{array}{l}\text { Crafts of Gharb Soheil are authentic } \\
\text { and unique }\end{array}$} & Freq. & & & 72 & 186 & 134 & \multirow[t]{2}{*}{4.16} & \multirow[t]{2}{*}{0.708} \\
\hline & & $\%$ & & & 18.4 & 47.4 & 34.2 & & \\
\hline \multirow[t]{2}{*}{4} & \multirow{2}{*}{$\begin{array}{l}\text { Crafts of Gharb Soheil help sustain } \\
\text { the local heritage }\end{array}$} & Freq. & & & 48 & 171 & 173 & \multirow[t]{2}{*}{4.32} & \multirow[t]{2}{*}{0.681} \\
\hline & & $\%$ & & & 12.2 & 43.6 & 44.1 & & \\
\hline \multirow[t]{2}{*}{5} & \multirow{2}{*}{$\begin{array}{l}\text { Crafts of Gharb Soheil reflect the } \\
\text { local culture of the village }\end{array}$} & Freq. & & & 48 & 133 & 211 & \multirow[t]{2}{*}{4.42} & \multirow[t]{2}{*}{0.699} \\
\hline & & $\%$ & & & 12.2 & 33.9 & 53.8 & & \\
\hline \multicolumn{8}{|c|}{ Average } & 4.21 & 0.718 \\
\hline & & & Pric & & & & & & \\
\hline No. & Attributes & & & & espon & & & Mean & Standard \\
\hline & & & 1 & 2 & 3 & 4 & 5 & & Deviation \\
\hline 1 & Crafts of Gharb Soheil village have & Freq. & & 40 & 118 & 171 & 63 & 3.66 & 0.868 \\
\hline & a fair price & $\%$ & & 10.2 & 30.1 & 43.6 & 16.1 & & \\
\hline 2 & Crafts of Gharb Soheil village have & Freq. & & 32 & 126 & 203 & 31 & 3.59 & 0.751 \\
\hline & $\begin{array}{l}\text { a fair price in comparison with } \\
\text { other places }\end{array}$ & $\%$ & & 8.2 & 32.1 & 51.8 & 7.9 & & \\
\hline 3 & You got a good value in return of & Freq. & & 8 & 110 & 211 & 63 & 3.84 & 0.706 \\
\hline & buying crafts in Gharb Soheil & $\%$ & & 2.0 & 28.1 & 53.8 & 16.1 & & \\
\hline 4 & You felt badly exploited after & Freq. & 61 & 204 & 87 & 32 & 8 & 2.29 & 0.897 \\
\hline & buying crafts in Gharb Soheil & $\%$ & $\begin{array}{c}15 . \\
6\end{array}$ & 52.0 & 22.2 & 8.2 & 2.0 & & \\
\hline & Avel & age & & & & & & 3.35 & 0.805 \\
\hline & & & 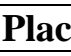 & & & & & & \\
\hline No. & Attributes & & & & espon & & & Mean & Standard \\
\hline & & & 1 & 2 & 3 & 4 & 5 & & Deviation \\
\hline 1 & The location of Gharb Soheil & Freq. & & & 64 & 146 & 182 & 4.30 & 0.734 \\
\hline & $\begin{array}{l}\text { village gives the impression of } \\
\text { authenticity }\end{array}$ & $\%$ & & & 16.3 & 37.2 & 46.4 & & \\
\hline 2 & The exterior appearance of Gharb & Freq. & & & 72 & 147 & 173 & 4.26 & 0.748 \\
\hline & $\begin{array}{l}\text { Soheil village gives the impression } \\
\text { of authenticity and uniqueness }\end{array}$ & $\%$ & & & 18.4 & 37.5 & 44.1 & & \\
\hline 3 & The local environment of Gharb & Freq. & 8 & & 56 & 179 & 149 & 4.18 & 0.823 \\
\hline & $\begin{array}{l}\text { Soheil village reflects the local } \\
\text { culture and traditions }\end{array}$ & $\%$ & 2.0 & & 14.3 & 45.7 & 38.0 & & \\
\hline
\end{tabular}


International Journal of Heritage, Tourism and Hospitality Vol. (14), No. (3) Spsecial Issue

\begin{tabular}{|c|c|c|c|c|c|c|c|c|c|}
\hline \multirow[t]{2}{*}{4} & Gharb Soheil crafts village has a & Freq. & 8 & 16 & 110 & 218 & 40 & \multirow[t]{2}{*}{3.68} & \multirow[t]{2}{*}{0.792} \\
\hline & $\begin{array}{l}\text { good standard of infrastructure, } \\
\text { such as water/electricity }\end{array}$ & $\%$ & 2.0 & 4.1 & 28.1 & 55.6 & 10.2 & & \\
\hline \multirow[t]{2}{*}{5} & \multirow{2}{*}{$\begin{array}{l}\text { Gharb Soheil crafts village has a } \\
\text { good standard of superstructure, } \\
\text { such as transport }\end{array}$} & Freq. & & 16 & 119 & 225 & 32 & \multirow[t]{2}{*}{3.70} & \multirow[t]{2}{*}{0.676} \\
\hline & & $\%$ & & 4.1 & 30.4 & 57.4 & 8.2 & & \\
\hline \multirow[t]{2}{*}{6} & \multirow{2}{*}{$\begin{array}{l}\text { Gharb Soheil crafts village has a } \\
\text { good standard of tourists facilities } \\
\text { and services }\end{array}$} & Freq. & & 39 & 180 & 126 & 47 & \multirow[t]{2}{*}{3.46} & \multirow[t]{2}{*}{0.830} \\
\hline & & $\%$ & & 9.9 & 45.9 & 32.1 & 12.0 & & \\
\hline \multirow[t]{2}{*}{7} & \multirow{2}{*}{$\begin{array}{l}\text { The remoteness of Gharb Soheil } \\
\text { crafts village can hinder you from } \\
\text { visiting it }\end{array}$} & Freq. & 7 & 134 & 88 & 123 & 40 & \multirow[t]{2}{*}{3.14} & \multirow[t]{2}{*}{1.058} \\
\hline & & $\%$ & 1.8 & 34.2 & 22.4 & 31.4 & 10.2 & & \\
\hline \multirow[t]{2}{*}{8} & \multirow{2}{*}{$\begin{array}{l}\text { You recommend Gharb Sohiel } \\
\text { crafts village for friends and family }\end{array}$} & Freq. & & & 87 & 234 & 71 & \multirow[t]{2}{*}{3.96} & \multirow[t]{2}{*}{0.634} \\
\hline & & $\%$ & & & 22.2 & 59.7 & 18.1 & & \\
\hline \multicolumn{8}{|c|}{ Average } & 3.83 & 0.786 \\
\hline \multicolumn{10}{|c|}{ d- Promotion: } \\
\hline \multirow[t]{2}{*}{ No. } & \multirow{2}{*}{\multicolumn{2}{|c|}{ Attributes }} & \multicolumn{5}{|c|}{ Responds } & \multirow[t]{2}{*}{ Mean } & \multirow{2}{*}{$\begin{array}{l}\text { Standard } \\
\text { Deviation }\end{array}$} \\
\hline & & & 1 & 2 & 3 & 4 & 5 & & \\
\hline \multirow[t]{2}{*}{1} & \multirow{2}{*}{$\begin{array}{l}\text { There is a difficulty in getting } \\
\text { information about the crafts village } \\
\text { of Gharb Soheil }\end{array}$} & Freq. & & 103 & 94 & 171 & 24 & 3.30 & 0.927 \\
\hline & & $\%$ & & 26.3 & 24.0 & 43.6 & 6.1 & & \\
\hline 2 & Information and data about Gharb & Freq. & 8 & 62 & 179 & 143 & & 3.17 & 0.761 \\
\hline & $\begin{array}{l}\text { Soheil crafts village are available in } \\
\text { travel agencies }\end{array}$ & $\%$ & 2.0 & 15.8 & 45.7 & 36.5 & & & \\
\hline 3 & Information and data about Gharb & Freq. & 8 & 117 & 180 & 79 & 8 & 2.90 & 0.810 \\
\hline & $\begin{array}{l}\text { Soheil crafts village are available in } \\
\text { tourist brochures }\end{array}$ & $\%$ & 2.0 & 29.8 & 45.9 & 20.2 & 2.0 & & \\
\hline 4 & Information and data about Gharb & Freq. & & 71 & 188 & 125 & 8 & 3.18 & 0.742 \\
\hline & $\begin{array}{l}\text { Soheil crafts village are available in } \\
\text { online travel websites }\end{array}$ & $\%$ & & 18.1 & 48.0 & 31.9 & 2.0 & & \\
\hline 5 & Online data about Gharb Soheil was & Freq. & & 94 & 196 & 102 & & 3.02 & 0.708 \\
\hline & & $\%$ & & 24.0 & 50.0 & 26.0 & & & \\
\hline 6 & There are positive reviews about & Freq. & 8 & 48 & 209 & 119 & 8 & 3.18 & 0.747 \\
\hline & websites & $\%$ & 2.0 & 12.2 & 53.3 & 30.4 & 2.0 & & \\
\hline 7 & Gharb Soheil crafts village is & Freq. & 16 & 55 & 217 & 72 & 32 & 3.13 & 0.895 \\
\hline & $\begin{array}{l}\text { 1ncluded in Egyptian tourism } \\
\text { programmes }\end{array}$ & $\%$ & 4.1 & 14.0 & 55.4 & 18.4 & 8.2 & & \\
\hline 8 & There is a difficulty in getting & Freq. & 48 & 101 & 134 & 109 & & 2.78 & 0.989 \\
\hline & of Gharb & $\%$ & $\begin{array}{c}12 . \\
2\end{array}$ & 25.8 & 34.2 & 27.8 & & & \\
\hline & $\mathbf{A v e}$ & ge & & & & & & 3.08 & 0.822 \\
\hline & & & eor & & & & & & \\
\hline No. & Attributes & & & & espon & & & Mean & Standard \\
\hline
\end{tabular}




\begin{tabular}{|c|c|c|c|c|c|c|c|c|c|}
\hline & & & 1 & 2 & 3 & 4 & 5 & & Deviation \\
\hline \multirow[t]{2}{*}{1} & \multirow{2}{*}{$\begin{array}{l}\text { Local people of Gharb } \\
\text { village are } \\
\text { helcoming }\end{array}$} & Freq. & & & 71 & 148 & 173 & \multirow[t]{2}{*}{4.26} & \multirow[t]{2}{*}{0.746} \\
\hline & & $\%$ & & & 18.1 & 37.8 & 44.1 & & \\
\hline \multirow[t]{2}{*}{2} & \multirow{2}{*}{$\begin{array}{l}\text { Local people of Gharb Soheil village } \\
\text { are friendly and helpful }\end{array}$} & Freq. & & & 56 & 172 & 164 & \multirow[t]{2}{*}{4.28} & \multirow[t]{2}{*}{0.698} \\
\hline & & $\%$ & & & 14.3 & 43.9 & 41.8 & & \\
\hline \multirow[t]{2}{*}{3} & \multirow{2}{*}{$\begin{array}{l}\text { People's local language affected } \\
\text { negatively on your satisfaction }\end{array}$} & Freq. & 53 & 88 & 132 & 103 & 16 & \multirow[t]{2}{*}{2.85} & \multirow[t]{2}{*}{1.082} \\
\hline & & $\%$ & $\begin{array}{c}13 . \\
5\end{array}$ & 22.4 & 33.7 & 26.3 & 4.1 & & \\
\hline \multirow[t]{2}{*}{4} & \multirow{2}{*}{$\begin{array}{l}\text { You were encouraged to participate } \\
\text { in the village's local cultural } \\
\text { activities with local people }\end{array}$} & Freq. & & 40 & 181 & 139 & 32 & \multirow[t]{2}{*}{3.42} & \multirow[t]{2}{*}{0.782} \\
\hline & & $\%$ & & 10.2 & 46.2 & 35.5 & 8.2 & & \\
\hline \multirow[t]{2}{*}{5} & \multirow{2}{*}{$\begin{array}{l}\text { You felt safe amongst local people } \\
\text { during your visit to Gharb Soheil } \\
\text { village }\end{array}$} & Freq. & & & 95 & 158 & 139 & \multirow[t]{2}{*}{4.11} & \multirow[t]{2}{*}{0.765} \\
\hline & & $\%$ & & & 24.2 & 40.3 & 35.5 & & \\
\hline \multicolumn{8}{|c|}{ Average } & 3.78 & 0.814 \\
\hline
\end{tabular}

$* 1=$ Strongly disagree, 2 = Disagree, 3 = Neutral, 4 = Agree, and 5 = Strongly disagree

The previous table (16) revealed some important facts concerning the significant cultural value of Gharb Soheil and its marketing process; depending upon product, place, price, promotion and people, as indicated in the following points:

\section{a- Product:}

According to the previous findings regarding the product, it appears that there is a general strong agreement on tourists' perception concerning the importance of the cultural value of the Gharb Soheil's local crafts; representing a mean average of 4.21. The majority of tourists strongly agreed on the following three statements, which are: "crafts of Gharb Soheil reflect the local culture of the village"; representing a mean of 4.42, "crafts of Gharb Soheil help sustain the local heritage"; representing a mean of 4.32", and "you are interested in buying crafts"; representing a mean of 4.21. On the other hand, tourists agreed on two statements, which are "crafts of Ghrab Soheil are authentic and unique"; representing a mean of 4.16, and "you are interested in crafts making activities; representing a mean of 3.19. These results prove the connection amongst crafts villages, culture and heritage, and confirm that tourists are aware of it. It also reflects the wants and desires of the targeted markets of crafts villages in both of buying crafts and participating in crafts making activities.

\section{b- Price:}

According to the previous findings of price, it appears that tourists were neutral on their perception concerning the prices' moderation and fairness of the Gharb Soheil local crafts; representing a mean average of 3.35. The majority of tourists agreed on the following three statements, which are "you got a good value in return of buying crafts in Gharb Soheil", representing a mean of 3.84, "crafts of Gharb Soheil village have a fair price"; representing a mean of 3.66., and "crafts of Gharb Soheil village have a fair price in comparison with other places; representing a mean of 3.59. They disagreed on one statement, which is "you felt badly exploited after buying crafts in Gharb Soheil"; representing a mean of 2.29. The mentioned results confirms the competitive advantage of Gharb Soheil crafts represented in their uniqueness and authenticity in comparison with prices, which can be useful when planning the marketing strategy.

\section{c- Place:}


According to the previous findings of place, it appears that there is a general agreement on Gharb Soheil crafts village as an authentic and unique tourist place; representing a mean average of 3.83. The majority of tourists agreed on the following statements, which are "the local environment of Gharb Soheil village reflects the local culture and traditions"; representing a mean of 4.18, "you recommend Gharb Sohiel crafts village for friends and family"; representing a mean of 3.96, "Gharb Soheil crafts village has a good standard of superstructure, such as transport"; representing a mean of 3.70, "Gharb Soheil crafts village has a good standard of infrastructure, such as water/electricity"; representing a mean of 3.68, and "Gharb Soheil crafts village has a good standard of tourists' facilities and services"; representing a mean of 3.46. On the other side, tourists strongly agreed on two statements, which are "the location of Gharb Soheil gives the impression of authenticity"; representing a mean of 4.30, and "the exterior appearance of Gharb Soheil village gives the impression of authenticity and uniqueness"; representing a mean of 4.26. They were neutral on one statement, which is "the remoteness of Gharb Soheil crafts village can hinder you from visiting it"; representing a mean of 3.14. The mentioned results indicate to the attractive aspects of Gharb Soheil as a tourism destination, as it contains both of tangible and intangible attractions as well as tourists' facilities and services.

\section{d- Promotion:}

According to the previous findings, it appears that tourists' perception on Gharb Soheil's promotion and marketing is neutral; representing a mean average of 3.08, as indicated. Tourists were neutral on all statements, which are "there is a difficulty in getting information about the crafts village of Gharb Soheil"; representing a mean of 3.30, "information and data about Gharb Soheil crafts village are available in online travel websites"; representing a mean of 3.18, "there are positive reviews about Gharb Soheil in online tourism websites"; representing a mean of 3.18, "information and data about Gharb Soheil crafts village are available in travel agencies"; representing a mean of 3.17, "Gharb Soheil crafts village is included in Egyptian tourism programmes"; representing a mean of 3.13, "online data about Gharb Soheil was available and satisfying"; representing a mean of 3.02, "information and data about Gharb Soheil crafts village are available in tourist brochures"; representing a mean of 2.90 , and finally "there is a difficulty in getting information about the crafts village of Gharb Soheil"; representing a mean of 2.78. The mentioned results show that there is a defect in the tourism promotion for Gharb Soheil, as the majority of responses to the statements were neutral. This is also consistent with the result of table (13), which indicated that tourists knew about Gharb Soheil from tour guides, family and friends.

\section{e- People:}

According to the previous findings of people, it appears that tourists' agree on the friendliness and good welcoming of local people of Gharb Soheil crafts village; representing a mean average of 3.78. Tourists strongly agreed on two statements, which are "local people of Gharb Soheil village are friendly and helpful"; representing a mean of 4.28, and "local people of Gharb Soheil village are hospitable and welcoming"; representing a mean of 4.26. They agreed on two statements, which are "you felt safe amongst local people during your visit to Gharb Soheil village"; representing a mean of 4.11, and "you were encouraged to participate in the village's local cultural activities with local people"; representing a mean of 3.42. They were neutral on one statement, which is "people's local language affected negatively on your satisfaction"; representing a mean of 2.85. The above results imply the importance of human resources in attracting tourists and affecting on their satisfaction, which is well-addressed and well-presented in Gharb Soheil. 


\section{SWOT Analysis Concerning Gharb Soheil Crafts Village:}

According to the previous findings, the following SWOT analysis presented in table (17), summarises the overall present situation of Gharb Soheil crafts village including its products, prices, place, promotion and people, as indicated:

Table (17): SWOT Analysis of Gharb Soheil Crafts Village

\begin{tabular}{|c|c|}
\hline Strengths & Weaknesses \\
\hline $\begin{array}{l}\text { - The importance of Gharb Soheil as an attraction } \\
\text { of a high cultural value. } \\
\text { - The uniqueness and authenticity of Gharb Soheil } \\
\text { as a place. } \\
\text { - The competitive advantage of crafts in Gharb } \\
\text { Soheil. } \\
\text { - The variation of crafts in Gharb Soheil. } \\
\text { - The faire price of Gharb Soheil crafts. } \\
\text { - The attraction of tourists from different } \\
\text { nationalities to Gharb Soheil crafts village. } \\
\text { - The good hospitality and friendliness of local } \\
\text { inhabitants in Gharb Soheil. } \\
\text { - The preservation of identity and variation in } \\
\text { customs and traditions. } \\
\text { - The safety and security. }\end{array}$ & $\begin{array}{l}\text { - Difficulties in visiting Gharb Soheil due to lack } \\
\text { of data, remoteness of the village, accessibility } \\
\text { problems, time limitations problems and lack of } \\
\text { tourists facilities and services. } \\
\text { - Lack of digital data about Gharb Soheil e.g. } \\
\text { websites and social media data. } \\
\text { - Lack of sufficient infrastructure and } \\
\text { superstructure in Gharb Soheil } \\
\text { - Lack of promotion and marketing about Gharb } \\
\text { Soheil. } \\
\text { - Lack of public and private sectors' support to } \\
\text { Gharb Soheil. }\end{array}$ \\
\hline Opportunities & Threats \\
\hline $\begin{array}{l}\text { - The authentic value of Gharb Soheil as a place } \\
\text { and its unique crafts as tourist souvenirs are } \\
\text { chances for enriching cultural tourism in Egypt } \\
\text { and protecting the Egyptian cultural heritage. }\end{array}$ & $\begin{array}{l}\text { - Tourists' attraction to other crafts villages in } \\
\text { other countries. } \\
\text { - The modern international changes. } \\
\text { - The change in peoples taste and trends. }\end{array}$ \\
\hline
\end{tabular}

\section{Conclusion}

This paper has presented an investigation into Marketing Egyptian Crafts Villages for Preserving the Cultural Heritage; applied on the Nubian Village of Gharb Soheil". According to the findings of the study, it was found out that crafts constitute an important component in cultural tourists' holidays, particularly youth tourists. Therefore, many cultural tourists are keen on visiting crafts villages and save up money for buying crafts as souvenirs in their trips and holidays. Gharb Soheil is considered an important cultural hub for cultural tourists due to its location, local people's life style and local crafts. Local crafts of Gharb Soheil are varied and are characterised by their authenticity and uniqueness. Therefore, they are important for representing the cultural identity of the village's local community and preserving its cultural heritage. The findings also proved that crafts of Gharb Soheil have a reasonable price and add a real value to tourists. Local people of Gharb Soheil are friendly and welcoming, and tourists face no bad exploitation by them in their visits to the village. Due to the cultural importance of Gharb Soheil and the distinguished crafts it has, many tourists are attracted to it particularly those tourists who visit places in the vicinity of the village e.g. Aswan. However, there some negatives concerning Gharb Soheil village as a tourism destination. These negatives are represented in the insufficient tourist facilities of the village. Furthermore, the village is not included in tourists' brochures and not widely existed in travel agencies' tourism programmes, and as a result tourists' visits to Gharb Soheil are highly dependent upon the recommendations of tour guides or friends. Thus, it can be inferred from these findings that Gharb Soheil crafts village needs a more effective marketing plan.

\section{Recommendations addressed to the Egyptian Ministry of Tourism and Antiquities:}


- Paying attention generally to crafts villages and particularly to Gharb Soheil as an important cultural hub for traditional crafts in Egypt.

- Carrying out a co-operation between the public sector and private sector for offering more tourism facilities and services, as well as providing infrastructure and superstructure in Gharb Soheil.

- Establishing educational centres for developing the crafts making skills for the local people of Gharb Soheil, as a way for sustaining local crafts.

- Carrying out periodical market researches, so that the tourism market of Gharb Soheil can be targeted and segmented for offering its needs and wants, and the forthcoming tourism market of Gharb Soheil can be identified.

- Choosing effective methods of promotion for Gharb Soheil as a cultural tourism destination by for instance, setting up an official website of many languages concerning Gharb Soheil and its local crafts, including Gharb Soheil on tourism and holidays websites as an Egyptian site of attraction, encouraging travel agencies to include Gharb Soheil as well as other similar Egyptian crafts villages in their tourism programmes by providing them advantages and privileges, and issuing publications $e . g$. brochures about these destinations to be in included in travel agencies and tourism offices.

- Producing documentaries about Gharb Soheil and its distinguished crafts for raising tourists' awareness about its cultural value.

- Carrying out a co-operation between the private sector and public sector for branding the crafts village of Gharb Soheil and consequently realising a competitive advantage for the village.

- Carrying out periodical post purchase and post visit researches for measuring tourists' satisfaction of Gharb Soheil as place and its crafts as a product so that any problems found can be tackled.

\section{References}

Ahmed, A. (2005). Tourism Village: A Conceptual Approach, Asia- Europe Seminar on Cultural Heritage, Man and Tourism in Honoi-Vietnam.

Ashley, C. (2006). How Can Governments Boost the Local Economic Impacts of Tourism: Options and Tools, A Workshop in the Overseas Development Institute, Westminster Bridge Road, London, UK.

Balayan, M. (2006). Souq El-Fustat. Horus: In-flight Magazine of Egypt Air, 24(2), 13-14.

Benson, W. (2014). The Benefits of Tourism Handicraft Sales at Mwenge Handicrafts Centre in Dar El-Salam, Tanzania, Bachelor's Thesis, Tempere University of Applied Sciences, Tempere, Finland.

Dang, T. D., Mahanty, S. and Vang, N. T. (2010). Vietnam's Craft Villages and Water Pollution: A Review of Previous Research, Working Paper for the Project Crafting Sustainability: Addressing Water Pollution from Vietnams Craft Villages, Australian National University, Canberra, Australia.

Dash, M. and Chodimella, V. K. (2011). Marketing of Handicrafts-A Challenge for Artisans: A Case of Orissa State-India. Research Journal of Social Science and Management, 1(3), 127-144.

Dodd, F. and Morgan, A. (2013). Defining and Measuring of Crafts: A Review for the Crafts Council, Report 1. Definitions 1998-2012, 1-19. 
Elcheikh, Z. (2013). Cultural Tourism Planning Impact on Saving Identity and Economic Development, Unpublished Master Thesis in Integrated Urbanism and Sustainable Design, Ain Shams University and University of Stuttgart.

Elcheikh, Z. (2014). Outside the Walls of the Nubian Museum. Annual Digital Journal on Research in Conservation and Cultural Heritage, 4, 30-37.

Elcheikh, Z. (2015). Interpretation in Cultural Tourism: Nubian Culture in Southern Egypt, Furnace IIICH, 1, 19-26.

El Cheikh, Z. (2016). Cultural Tourism between Identity and Income: The Case of the Nubian Village of Gharb Soheil, Chronos, 2016 (33), 155-172.

Elcheikh, Z. (2018). Tales from Two Villages: Nubian Women and Cultural Tourism in Gharb Soheil and Ballana, Dotawo. A Journal of Nubian Studies, 5(3), 241-260.

El Gamil, R. (2017). Storytelling as a Tool for Safeguarding and Marketing The Intangible Cultural Heritage (ICH). The Case of Nubia City, Egypt, Tourism Research Institute, Journal of Tourism research, 18(1), 165-185.

Fahmi, S. (2012). Sustainable Tourism and the Rehabilitation of Cairo's Historical District. the Case of the Bazaar Area and Cities of Dead, $2^{\text {nd }}$ World Sustainability Forum, 1-29.

Fanchette, S. (2012). Local Agri-Food Systems in a Global World: Market, Social and Environmental Challenges, Chapter 6. The Craft Villages of the Red River Delta (Vietnam). Periodization, Spatialization, Specialization, Cambridge Scholar Publishing, UK.

Gamble, J. R., Gilmore, A., McCartan-Quinn, D. and Durkan, P. (2011). The Marketing Concept in the $21^{\text {st }}$ Century. A Review of How Marketing Has Been Define Since the 1960s, The marketing Review 11(3), DOI. 10.1362/146934711X589444, 1-22.

Geith, A. A. K. (2008). Crafts in Khan El-Khalili. A Study in the Economic Geography by Using the Geographic Information System, [In Arabic], Unpublished Master Thesis, Department of Geography, Faculty of Women for Arts, Science and Education, Ain Shams University, Cairo, Egypt.

Gustami, S., Wardani, L. K. and Setiawan, A. H. (2014). Craft Arts and Tourism in Ceramic Art Village in Yogyakarta. Journal of Arts and Humanities, 3(2), 37-49.

Hieu, V. M. and Rasovska, I. (2017). Craft Villages and Tourism Development: A Case Study in Phu Quoc Island of Vietnam. Management, 21(1), 223-236.

Hien, N. V. (2012). Sustainable Development of Traditional Villages in Vietnam for Global Market Integration. Journal of Development and Integrations News, UEF, 4(14), 31-42.

Hussien, S. M. (2018). Khan El-Khalili in the Ottoman Era: A Historical and a Documentary Study, [In Arabic], Journal of Middle East Research Center, 3(45), 27-60.

Jain, R. and Thakkar, J. (2019). "Experiencing Craft and Culture: An Emerging Cultural Sustainable Tourism Model in India", Available on. httpll:www.researchgate.net/publication/332600019. Accessed on: 28 January 2020; 01.25 AM.

Jennings, H. (2012). Towards a Definition of Heritage Craft, Creative and Cultural Skills, the National Skills Academy, 1-30.

Khalil, S. (2018). Women Empowerment in Marginalized Villages via Tourism: A Case Study of Aswan Governorate, Egypt. International Journal of Heritage, Tourism and Hospitality, 12(2/2), 19-31.

Khan, W. A. and Amir, Z. (2013). Study of Handicrafts Marketing Strategies of Artisans in Uttar Pradesh and Its Implications. Research Journal of management and Sciences, 2(2), 23-26. 
Khurana, C. (2011). Consumer Reference and Satisfaction towards Selected Handicrafts Items with Special Reference to Jaipur City, Doctoral Dissertation, Department of Management, faculty of Commerce and Management, IIS University, India.

Kouhia, A. (2012). Categorizing the Meaning of Crafts: A Multi-perspective Framework for Eight Interrelated Meaning Categories, Techne Series, 19(1), 25-40.

Luong, P.T. (2006). Craft Village Based Tourism: Current Situation and Development Orientation in Vietnam, APEC/SME Seminar on Support for Local and Cottage Industries, $21^{\text {st }}$ September.

Mahgoub, Y. M. and Alsoud, K. M. (2015). The Impact of Handicrafts on the Promotion of Cultural and Economic Development for Students of Art Education in Higher Education. Journal of Literature and Art Studies, 5(6), 471-479.

McAuley, A. and Fillis, I. (2005). Careers and Lifestyles of Craft Makers in the $21^{\text {st }}$ Century, Cultural Trends, Routledge, 14(2), 139-156.

Mustafa, M. (2011). Potential of Sustaining Handicrafts as a Tourism Product in Jordan. International Journal of Business and Social Science, 2(2), 145-152.

Orabi, R. M. (2019). Studying the Effect of Sharing Economy on the Tourism Industry: Developing the Local Economy for the Nubian Community. An Empirical Study Using the Gharb Soheil Village, African Journal of Hospitality. Tourism and Leisure, 8(5), 1-21.

Pallant, J. (2016). SPSS Survival Manual, $6^{\text {th }}$ Ed., McGraw-Hill Education, Berkshire, UK.

Pollanen, S. (2012). The Meaning of Craft. Craft Makers Descriptions of Craft as an Occupation. Scandinavian Journal of Occupational Therapy, 20(3).

Radwan, W. R. M. I. (2016). The Role of Tunis Village in Fayoum Governorate as a Cultural Tourism Model. Journal of Association of Arab Universities for Tourism and Hospitality, 13(1), 209-220.

Ribasauskiene, E. and Sumyle, D. (2016). The Role of Traditional Crafts Center in Safeguarding Cultural Heritage. Management Theory and Studies for Rural Business and Infrastructure Development, 38(4), 412-424.

Rouhi, J. (2017). Definition of Cultural Heritage Prosperities and their Values by the Past. Asian Journal of Science and Technology, 8(12), 7109-7114.

Saleh, Y. (2006). Cut From a Different Cloth: A Unique Egyptian Weaving Tradition Calls out for Preservation. Horus. In-flight Magazine of Egypt Air, 24(2), 14-15.

Shakiya, M. (2018). Handicrafts and Tourism: A Case Study on the Role of Handicrafts and Arts for Tourism Development in Patan, Unpublished Thesis for Higher Diploma in Hotel and Restaurant Management, the Global Academy for Tourism and Hospitality, Mandikhatar, Kathmandu, Nepal.

Schwarz, M. and Yair, K. (2010). Making Value: Craft and the Economic and Social Contribution of Makers, Crafts Council, London UK.

Shrestha, R. (2011). Crafts Village at Madhyapur Thimi, Unpublished Bachelor Thesis of Architecture, the Department of Architecture, Institute of Engineering, Tribhuvan University, Nepal.

Suthersanen, U. (2015). Protection of Handicraft Goods and Traditional Cultural Expressions: A Copyright Perspective, IP4Growth.

Suzuki, N. (2006). "Effective Tourism Development through Traditional Craft Promotion: Japanese Experiences, $1^{\text {ST }}$ International Conference on Tourism and Traditional Craft and Associated Activities, Riyadh, KSA. 
Swanson, K. K. (2004). Tourists and Retailer's Perceptions of Souvenirs. Journal of Vocational Marketing, 10(4), 363-377.

Tissari, J. (2010). Wooden Craft development in Kim Bong Village, Kim Bong Village Community Based Tourism Project, Hoi An District, Quang Nam Providence, Vietnam Consultant's Final Report, Export-Led Poverty Reduction Program, International Trade Centre.

United Nations Environment Programme and the World Tourism Organisation (2005): Making Tourism More Sustainable. A Guide for Policy Makers, A Report by United Nations Environment Program and World Tourism Organization.

Wang, Z. (2017). Analysis on Application of Traditional Arts and Crafts in Exhibition Design. Open Journal of Social Sciences, 5, 85-89.

Wicks, B., Do, K., Hsieh, P., Komorowski, A., Martin, K., Qiu, X., Rimdzius, M., Strzelecka, M., Wade, K. and Yu, G. (2004). Direct Marketing of Crafts and Souvenirs to Vladimir Visitors", Department of Recreation, Sport and Tourism, College of Applied Studies, University of Illinois, USA.

World Intellectual Property Organization (2003). Marketing Crafts and Visual Arts: the Role of Intellectual Property, International Trade Center, UNCIADIWTO, Geneva, Switzerland.

Yang, Y., Shafi, M., Song, X. and Yang, R. (2018). Preservation of Cultural Heritage Embodied in Traditional Crafts in the Developing Countries: A Case Study of Pakistani Handicraft Industry. Sustainability Journal, 10(1336), 2-18. 